\title{
PELAKSANAAN INTEGRASI PENDIDIKAN KARAKTER DALAM MATA PELAJARAN AQIDAH AKHLAK SISWA KLS X DI MAN 1 MEDAN
}

\author{
Ahmad Darwis \\ Universitas Muslim Nusantara Al Washliyah Medan \\ ahmad_darwis2001@Yahoo.com
}

\begin{abstract}
Abstrak
Karakter adalah merupakan hal yang sangat penting dan mendasar. Mengingat begitu pentingnya karakter maka lembaga pendidikan hendaknya memiliki tanggung jawab yang besar untuk menanamkan pembentukan karakter siswa. Sejauh ini dalam proses pendidikan di Indonesia yang berorientasi pada pembentukan karakter individu belum dapat dikatakan tercapai karena dalam prosesnya pendidikan di Indonesia terlalu mengedepankan penilian pencapaian individu dengan tolak ukur tertentu terutama logikmatematik Persoalan karakter memang tidak sepenuhnya terabaikan oleh lembaga Pendidikan. Hal ini karena apa yang diajarkan disekolah tentang pengetahuan agama dan pendidikan moral dan akhlak belum berhasil membentuk manusia yang berkarakter. Padahal apabila kita tilik isi dari semua pelajaran semuanya bagus, dan bahkan kita dapat memahami dan menghafal apa maksudnya. Untuk itu, kondisi dan fakta kemerosotan karakter dan moral yang terjadi menegaskan bahwa para guru yang mengajar mata pelajaran apa pun harus memiliki perhatian dan menekankan pentingnya pendidikan karakter pada para siswa. Tujuan umum penelitian ini adalah untuk memperoleh gambaran dan penjelasan tentang integrasi pendidikan karakter siswa dalam mata pelajaran Aqidah akhlak yang di terapkan di MAN 1 Medan. Metodologi penelitian ini didasarkan pada pendekatan kualitatif. Teknik pengumpulan data dilakukan dengan wawancara, observasi, dan dokumentasi, interview dan skala sikap. Hasil penelitian yang diperoleh adalah bahwa Integrasi pendidikan karakter dalam mata pelajaran aqidah Akhlak kelas $X$ di MAN 1 sudah berjalan dengan baik hal ini dapat dilihat adanya hubungan keterkaitan pada RPP dan Silabus serta pelaksanaan proses pembelajaran Aqidah Akhlak di kelas dalam pembentukan karakter siswa.
\end{abstract}

Kata kunci : pendidikan, karakter, pembelajaran

\begin{abstract}
Character is very important and fundamental. Consideringhow important the character, so educational institutions should have a great responsibility to instill the formation of student character. So far in the process of education in Indonesia oriented on the formation of individual characters can be said has not been achieved because in the process of education in Indonesia prioritize to achieved individual assessment with certain benchmarks, especially logic-mathematics. Character issues are not completely ignored by educational institutions. This is because what is taught in school about religious knowledge and moral and attitude education has not succeeded in forming a character human. Whereas when we look at the contents of all the sujects are all good, and even we can understand and memorize what it means. Therefore the conditions and facts of the deterioration of character and morals affirm that teachers who teach any subject must have attention and emphasize the importance of character education on the students. The general objective of this study is to obtain a description and explanation about the integration of character education in subjects moral attitude applied in MAN 1 Medan. This research methodology is based on qualitative approach. Data collection
\end{abstract}


techniques were conducted through interviews, observations, and documentation, interviews and attitude scales. The results obtained are that the integration of character education in subjects moral attitude class X in MAN 1 has been running well this can be seen the relationship of relationship in RPP and Syllabus and implementation of learning process moral attitude in the classroom in the formation of student character.

Keyword : education, characterr, learning

\section{PENDAHULUAN}

Pendidikan merupakan bagian dari kebudayaan dan peradaban manusia yang terus berkembang.Hal ini sejalan dengan pembawaan manusia yang memiliki potensi kreatifdan inovatif dalam segala bidang kehidupan.Pendidikan diartikan sebagai usaha manusia untuk membina kepribadiannya sesuai dengan nilai-nilai didalam masyarakat dankebudayaan.Secara singkat tujuan pendidikan Nasional ialah untuk menciptakan generasi yangmemiliki Ilmu Pengetahuan dan Teknologi serta memiliki Iman dan Taqwa yang kuat. Ini semua dapat diwujudkan dengan menyelenggarakan pendidikan sebagai salah satu jalan untuk mewujudkan Iman dan Taqwa yang kuat. Madrasah pada umumnya memang telah memberikan perhatian terhadap pembentukan akhlak, sebagaimana terlihat darikurikulum agama dan berbagai kegiatan keagamaan di sejumlah madrasah dewasa ini. Adapun mata pelajaran PAI yang dipelajari di MAN1 Medanmeliputi: Akidah Akhlak, AlQur'an dan Al-Hadis, Fikih, dan Sejarah Kebudayaan Islam(SKI).

Diantara mata pelajaran Pendidikan Agama Islam tersebut, Akidah Akhlakmerupakan mata pelajaran yang memiliki kontribusi besar dalam memberikan motivasikepada peserta didik untuk mempelajari dan mempraktikkan akidahnya dalam bentukpembiasaan untuk melakukan akhlak terpuji dan menghindari akhlak tercela dalamkehidupan sehari-hari.

Secara khusus penelitian ini bertujuan :

1. Mengetahui bagaimana pengembangan pelaksanaa pendidikan Karakter siswa Madrasah Aliyah Negeri 1Medan

2. Mengetahui bagaimana metode pembelajaran dalam pendidikan Karakter siswa Madrasah Aliyah Negeri 1 Medan.

3. Mengetahui bagaimana model Pendidikan Karakter siswa dalam aktivitas pembelajaran pendidikan agama, baik kurikuler, kokurikuler,maupun layanan konseling dan suasana yang di bangun dalam pendidikan Karakter siswa Madrasah Aliyah Negeri 1Medan .

4. Mengetahui faktor apa saja yang merupakan pendukung dan penghambat berbagai aktivitasaktivitas pembelajaran pendidikan agama dalam pendidikan karakter siswa Madrasa Aliyah Negeri 1 Medan..

5. Mengetahui hasil Pendidikan Karakter siswa Madrasah Aliyah Negeri 1 Medan.

\section{METODE}

Metode Penelitian yang digunakan adalah metodologis penelitian ini didasarkan pada pendekatan naturalistik yang sering 
disebut pendekatan kualitatif. Lokasi penelitian adalah di Madrasah aliyah Negeri 1 Medan. Di Jalan Pancing. Waktu penelitian lamanya di mulai dari bulan Mei 2016 sampai September 2017. Untuk mengumpulkan data dalam penelitian ini dipakai beberapa teknik pengumpulan data. Teknik pengumpulan data yang dimaksud adalah meliputi wawancara, observasi, dokumentasi, dan interview. Adapun subyek yang penulis wawancarai dalam penelitian ini adalah : (1) Kepala Sekolah (2) Guru Pendidikan Agama Islam, (3) Konselor .(4). Pembantu Kepala sekolah, (5).Siswa.

Teknik observasi, dalam penelitian kualitatif observasi diklasifikasikan menurut tiga cara, yaitu : (1) pengamat dapat bertindak sebagai seorang partisipan atau nonpartisipan, (2) observasi dapat dilakukan terus terang maupun penyamaran, (3) observasi yang menyangkut latar penelitian. Hasil observasi dalam penelitian ini dicatat dalam catatan lapangan.

Analisis data adalah proses pelacakan dan pengaturan secara sistematik transkip wawancara, catatan lapangan, bahan-bahan lain yang di kumpulkan untuk meningkatkan pemahaman terhadap bahan-bahan tersebut. Kegiatan analisis dimulai sejak atau bersamaan waktunya dengan prosespengumpulan data yang dilakukan secara bertingkat tiga atau empat kali tahapan, yaitu :

(1) penentuan fokus penelitian; (2) penyusunan temuan-temuan; pembuatan rencana pengumpulan data; (4) pengembangan pertanyaanpertanyaan analitik untuk mengumpulkan data berikutnya; (5) penetapan sasaran-sasaran pengumpulan data berikutnya. Hal ini dilakukan dalam rangka mengisi kekurangan-kekurangan data dan menguji hipotesis-hipotesis atau gagasan-gagasan yang muncul selama pengumpulan data. Proses analisis data pada penelitian kualitatif berlangsung sejak tahap orientasi sampai pelaporan hasil penelitian Langkah-langkah yang dikemukakan diatas menjadi pedoman pengolahan dan analisa data pada penelitian ini adalah:

a. Melakukan pengelompokan dan kategorisasi. Data mentah aktivitas pembelajaran dan pembentukan Karakter siswa mulai dariperencanaan, penilaian dikelas dan diluar kelas ,pembentukan akhlak melaluikegiatan eksta, peneladanan dan penciptaan suasana yang kondusif. Keseluruhandata lapangan yang memuat asfek-asfek yang diteliti dibuat secara rinci dalamcatatan lapangan.

b. Ringkasan (preduksian ) Data. Ringkasan data tersebut dengan membuat rangkuman terhadap asfek yang diteliti.

Untuk melihat gambaran secara keseluruhan aktivitas pembelajaran dalam rangka pembentukan Karakter siswa dikelas, diluar kelas data hasil penelitian ditata kembali dalam bentuk penyajian secara utuh, kemudian dilakukan interpretasi terhadap datatersebut. Kesimpulan ini dilakukan untuk mengambil hasil data penelitian lapangan dalambentuk pernyataan singkat dan mudah dipahami. Pengecekan keabsahan data., langkah yang dilakukan dengan Teknik-tekniknya : (1). Keikutsertaan yang diperpanjang, (2) pengamatan 
yangtekun, (3) triangulasi (teknik keabsahan data yang memanfaatkan sesuatu yang lain diluardata), (4) pengecekan sejawat melalui diskusi.

(5) kecukupan referensial.

\section{HASIL DAN PEMBAHASAN}

Dalam mengembangkan berpendidikan karakter yang holistik tersebut selain melalui proses pembelajaran yang semakin unggul, tidak kalah pentingnya dibangun dan dicontohkan model keteladanan dari seluruh pihak sehingga bagi subjek didik terdapat role model (model acuan) yang nyata bagaimana contoh berkarakter utama dalam kehidupan. Terdapat keteladanan bagaimana hidup benar, baik, jujur, tanggung jawab, disiplin, kasih sayang, taat aturan, dan sifat-sifat utama lainnya melalui proses yang bersifat edukatif, partisifatif,dan dapat diteladani secara nyata.

Bukankah pendidikan itu apapun jenis dan modelnya merupakan lembaga atau pranata untuk menjadikan anak manusia yang berakal-budi secara utuh, bukan untuk melahirkan para robot yang cerdas otak dan keahliannya tetapi lemah moral dan sosialnya, atau sebaliknya. (Haedar, 2013: 27)

Pendidikan di lembaga pesantren, madrasah maupun sekolah akan kehilangan fungsinya dan tidak banyak memberikan pengaruh terhadap karakter siswa jika semua pihak akademik tidak menampilkan contoh teladan dalam aktipitas kegiatan di lembaga tersebut. Karena siswa kehilangan sosok yang dapat di jadikan panutan dalam kehidupannya.

Pendidikan Islam bersumber dari ajaran Islam, AlQur'an, Hadits, dan Ijtihad.Prinsip umum Pendidikan Islam adalah pertautan yang sempurna dengan sunatullah dan Agama.Nilai-nilai pendidikan, tujuan, kurikulum, falsafah, kandungan, metode tak boleh membelakangi agama.Prinsip menyeluruh (universal) mencakup segala aspek pertumbuhan, pribadi, sosial, dan kehidupan. Prinsip integral (terpadu), integral antara unsur teosentris, imanitas dengan unsur antroposentris, manusia, dan dunia.

Prinsip keseimbangan. Imbang antara kebutuhan jasmani, rohani, lahir batin, dunia akhirat, kebutuhan masa kini, dan masa depan. Prinsip kejelasan, kejelasan prinsip, tujuan, ajaran dan hukumhukumnya. Prinsip fitratullahi bagi manusia.Pendidikan mengakui perbedaan-perbedaan individual diantara peserta didik, baik bakat, minat, kemauan, dan kebutuhan. Prinsip perubahan dan perkembangan selaras dinamika masyarakat. (Jejen Mustafa (E 2012: 260)

Sesuai apa yang dinyatakan oleh Elkind and sweet praktik persekolahan di Amerika Serikat pendidikan karakter dilaksanakan dengan pendekatan holistik (holistic approach). Artinya seluruh warga sekolah mulai dari guru, karyawan, dan para murid harus terlibat dan bertanggung jawab terhadap pelaksanaan pendidikan karakter. Hal ini paling penting disini adalah bahwa pengembangan karakter harus terintegrasi ke dalam setiap aspek kehidupan sekolah. Pendekatan semacam ini disebut juga reformasi sekolah menyeluruh. ( Muchlas ,2012: 139)

\section{Kegiatan Pendahuluan :}

a. Menyiapkan peserta didik secara psikis, 
b. Mengajukan pertanyaan mengaitkan dengan pengetahuan sebelumnya,

c. Menjelaskan tujuan pembelajaran atau kompetensi dasar yang akan di capai.

\section{Eksplorasi}

a. Guru melibatkan peserta didik dalam memuat informasi yang luas tentang topik/ tema materi yang akan dipelajari (mengajak siswa berfikir kritis),

b. Guru menggunakan beragam pendekatan pembelajaran, media pembelajaran, dan sumber belajar lain (sarana menyisipkan materi ).

\section{Elaborasi.}

a. Membiasakan peserta didik membaca dan menulis yang beragam melalui tugas-tugas tertentu yang bermakna (contoh nilai yang ditanamkan: cinta ilmu, kreatifdan logis)., b. Memfasilitasi peserta didik melalui pemberian tugas, diskusi, dan lain-lain untuk memunculkangagasan baru baik secaralisan maupun tertulis.,

c. Memberi kesempatan untuk berpikir, menganalisis, menyelesaikan masalah.

\section{Komfirmasi:}

Memberikan umpan balik positif dan penguatan dalam bentuk lisan,tulisan, isyarat, maupun hadiah terhadap keberhasilan peserta didik.

\section{Penutup}

a. Bersama-sama dengan peserta didik atau sendiri membuat rangkuman/simpulan pelajaran.

b. Melakukan penilaian dan/atau refleksi terhadap kegiatan yang sudah dilaksanakan secara konsisten.

Observasi peneliti :

\begin{tabular}{|c|l|c|c|}
\hline \multirow{2}{*}{ No. } & \multicolumn{1}{|c|}{ Tahap Penilaian Pembelajaran } & \multicolumn{2}{c|}{ Keterangan } \\
\hline & \multicolumn{1}{|c|}{ Ada } & Tidak \\
\hline 1. & Ranah penilaian & & \\
\hline & a. Kognitif & $\checkmark$ & \\
\hline & $\begin{array}{l}\text { b. Afektif (sikap peserta didik dalam } \\
\text { pembelajaran) }\end{array}$ & $\checkmark$ & \\
\hline & $\begin{array}{l}\text { c. Psikomotorik (keterampilan yang didapat } \\
\text { oleh peserta didik) }\end{array}$ & $\checkmark$ & \\
\hline 2. & Bentuk penilaian & & \\
\hline & a. Tes lisan dan Tulisan & $\checkmark$ & \\
\hline & c. Non tes, Perbuatan Skala sikap & $\checkmark$ & \\
\hline 3. & Waktu penilaian & & \\
\hline & a. Saat proses pembelajaran & $\checkmark$ & \\
\hline & b. Setelah proses pembelajaran & $\checkmark$ & \\
\hline & c. Akhir semester & $\checkmark$ & \\
\hline
\end{tabular}


Lembar Dokumentasi:

\begin{tabular}{|c|c|c|c|}
\hline \multirow{2}{*}{ No. } & \multirow{2}{*}{ Tahap Perencanaan Proses Pembelajaran } & \multicolumn{2}{|c|}{ Keterangan } \\
\hline & & Ada & Tidak \\
\hline 1. & Keberadaan Perencanaan Pembelajaran & & \\
\hline & $\begin{array}{l}\text { a. Silabus } \\
\text { b. RPP }\end{array}$ & $\checkmark$ & \\
\hline 2. & Kelengkapan komponen RPP & & \\
\hline & a. Identitas mata pelajaran & $\checkmark$ & \\
\hline & b. Standar Kompetensi & $\checkmark$ & \\
\hline & c. Kompetensi inti, dasa & $\checkmark$ & \\
\hline & d. Kompetensi Dasar & $\checkmark$ & \\
\hline & e. Indikator pencapaian kompetensi & $\checkmark$ & \\
\hline & f. Tujuan pembelajaran & $\checkmark$ & \\
\hline & g. Materi ajar & $\checkmark$ & \\
\hline & h. Alokasi waktu & $\checkmark$ & \\
\hline & $\begin{array}{l}\text { Metode pembelajaran (pengembangan nilai- Nilai } \\
\text { melalui penggunaan metode pembelajaran) }\end{array}$ & & \\
\hline & $\begin{array}{l}\text { Kegiatan pembelajaran (adanya kegiatan pembelajaran } \\
\text { yang mengembangkan karakter) } \\
\text { 1) Pendahuluan } \\
\text { 2) Inti } \\
\text { 3) Penutup }\end{array}$ & $\checkmark$ & \\
\hline & $\begin{array}{l}\text { Penilaian hasil belajar (adanya teknik penilaian yang } \\
\text { dapat mengembangkan dan/atau mengukur } \\
\text { perkembangan karakter). }\end{array}$ & $\checkmark$ & \\
\hline & k. Sumber belajar & $\checkmark$ & \\
\hline
\end{tabular}

\section{KESIMPULAN}

Secara umum para guru di MAN 1 Medan telah melakukan integrasi mata pelajaran dalam pendidikan karakter siswa. Penilaian dilakukan dengan baik, melalui pengamatan, dan wawancara. Hasil analisis menunjukkan bahwa mata pelajaran aqidah akhlak sudah terintegrasi dengan pembentukan karakter siswa, terlihat dari aktivitas kegiatan siswa. Pelaksanaan pembelajaran mata pelajaran aqidah akhlak sudah berjalan dengan baik denan melihat RPP dan silabus yang sudah di buat oleh guru MAN 1 Medan dan proses pembelajaran yang dilakukan.

\section{DAFTAR PUSTAKA}

Abdul Majid, Dian Andayani, Pendidikan Karakter Persfektif Islam (Bandung: PT Remaja Rosdakarya 2010

Abu Bakr Jabir Al-Jazairi, Minhajul Muslim terj Fadhli Bahri, Ensiklopedi Muslim Jakarta: Darul Falah,2002

Al -Abrasyi, Muhammad Athiyah, Prinsip-Prinsip Dasar Pendidikan Islam, Terj Bandung:CV Pustaka Setia, 2003

Fatchul Mu'in, Pendidikan Karakter konstuksi Teoretik dan Praktik, Yogyakarta: Ar ruzz Media: 2011 
Hamruni, Strategi Pembelajaran, Yogyakarta: InsanMadani, 2012

Kementrian Pendidikan Nasional Badan Penelitian Pengembangan Pusat Kurikulum,

Muslih, Masnuur, Pendidikan Karakter menjawab Tantangan Krisis Multi dimensional, (Jakarta :Bumi Aksara, 2011

Muchlas Samani, Hariyanto, Konsep dan Model Pendidikan Karakter, (Bandung: PT Remaja Rosdakarya, 2011

Mustafa, Jejen (Ed), Pendidikan holistic Pendekatan Lintas Persfektif (Jakarta: Kencana Prenada Media Group, 2012

Nashir, Haidar, Pendidikan Karakter Berbasis Agama dan Budaya, Yogyakarta: Multi Presindo, 2013

Sudewo, Erie, Character Building: Menuju Indonesia Lebih Baik, (Jakarta: Republika, 2011

Thomaslickona, Educating For Character Mendidik Untuk Membentuk Karakter Bagaimana Sekolah Dapat Mengajarkan Sikap Hormat dan Tanggung Jawab, (Jakarta :PT Bumi Aksara, 2013),h.70.

Zainal Aqib, Pendidikan Karakter di Sekolah Membngun Karakter dan Kepribadian Anak, Bandung: YramaWidya, 2012

Zubaedi, Desain Pendidikan Karakter Konsepsi dan Aplikasinya dalam lembaga Pendidikan ( Jakarta: Kencana Prenada Media Group 2012 